\title{
Revised Sentencing Guidelines and the Ex Post Facto Clause
}

\author{
William P. Ferranti $\dagger$
}

Federal judges must sentence convicted offenders according to guidelines promulgated and periodically revised by the United States Sentencing Commission ("The Commission"). 'By both statute and guideline, sentencing judges are required to apply the Guidelines Manual in effect at the time of sentencing. ${ }^{2}$ Citing the Ex Post Facto Clause, however, every circuit has rejected sentences produced by this rule where an applicable guideline was revised to the offender's detriment between the time the offense was committed and the time of sentencing. ${ }^{4}$

A more difficult situation arises when the defendant is convicted of two offenses, the first committed before, and the second after, a revised edition of the Guidelines Manual becomes effective. The guidelines direct the courts to apply the revised Manual to both offenses.' The circuit courts are split as to whether this violates the Ex Post Facto Clause. ${ }^{6}$ This Comment concludes that the provision requiring this result, §1B1.11(b)(3), is unconstitutional.

The Ex Post Facto Clause provides simply, "No ... ex post facto Law shall be passed." This prohibition is understood to extend to a special class of criminal laws - those that act retrospectively and to the disadvantage of the offender. "Critical to relief under the Ex Post Facto Clause is ... the lack of fair notice and governmental restraint when the legislature increases punishment beyond what was prescribed when the crime was consummated." While notice ex ante is

B.A. 1999, Columbia University; J.D. Candidate 2004, The University of Chicago. See 18 USC $\$ 3553$ (b) (2000).

See 18 USC $\S 3553(\mathrm{a})(4)$ (A); United States Sentencing Commission Guidelines Manual ("USSG") § 1B1.11(a), Policy Statement (“ps") (1998).

3 US Const Art I, § 9, cl 3.

4 See United States $v$ Schnell, 982 F2d 216, 218 (7th Cir 1992) (listing cases). See also United States $v$ Seacott, 15 F3d 1380, 1386 (7th Cir 1994) (joining other circuits in so holding). But see id at 1392 (Easterbrook concurring) (concluding sentencing guidelines are not laws for purposes of the Clause).

5 See USSG § 1B1.11(b)(3), ps.

6 See cases cited in note 115 .

7 US Const Art I, $\S 9, \mathrm{cl} 3$. The Constitution also includes a separate ex post facto clause directed at the states. See US Const Art I, $\S 10, \mathrm{cl} 1$.

8 See Calder v Bull, 3 US (3 Dall) 385, 390 (1798) (Chase).

9 Weaver v Graham, 450 US 24, 30 (1981). 
essential, unduly focusing on what a defendant ought to have known and when obscures the fact that the prohibition is a limit on governmental action. The Constitution does not provide defendants with a right to fair punishment, ${ }^{10}$ it prohibits ex post facto laws.

The Commission justifies applying revised guidelines retrospectively by legal analogy to relevant conduct sentencing and a policy concern with "anomalous" sentences. While a number of courts have treated these arguments favorably, judicial evaluation of $\S 1 \mathrm{~B} 1.11(\mathrm{~b})(3)$ tends to focus on whether the defendants were given fair warning that they would be subjected to the revised guidelines. The revisions themselves arguably provide constitutionally sufficient notice because $\S 1 \mathrm{~B} 1.11(\mathrm{~b})(3)$ does not trigger the increased punishment unless the offender commits further crimes after the revisions have gone into effect. While this formulation may vindicate the Clause's concern with fairness to the offender, none of these arguments addresses its concern with governmental restraint.

Parts I and II of this Comment provide an overview of the Sentencing Guidelines regime and explain how the guidelines fit within the scope of the ex post facto prohibition. Part III argues that $\S 1 \mathrm{~B} 1.11(\mathrm{~b})(3)$ is unconstitutional, and thus, where it applies, courts must either sentence all counts of conviction under the old Manual, or sentence the pre-revision counts under the old Manual and the postrevision counts under the new manual.

\section{THE SENTENCING GUIDELINES REgIME AND THE EX Post Facto ClaUSE}

The Sentencing Commission was created in $1984^{11}$ and charged with the production and regular revision of sentencing guidelines. ${ }^{12}$ Under the guidelines regime, the sentencing discretion of the federal district courts has been severely constrained. ${ }^{13}$ The inescapable conclusion is that the guidelines, rather than judges, now dictate the sentence imposed. ${ }^{14}$ Faced with judicial recognition of this reality, the Commission revised the guidelines to take account of the Ex Post Facto

10 See id.

11 See Sentencing Reform Act of 1984, Pub L No 98-473, ch II, 98 Stat 1987 (1984), codified as amended at 18 USC $\$ \S 3551-3673$ (2000) and 28 USC $\$ \S 991-98$ (2000).

12 See 28 USC $\$ 994(\mathrm{~b})(1)$ (stating that the Commission shall create the guidelines); $\S 994$ (o) (stating that the Commission shall periodically revise the guidelines); text accompanying notes $16-20$.

13 See 18 USC $\S 3553$ (b) (stating that courts must generally impose a sentence in accordance with the guidelines); text accompanying notes 21-25.

14 See United States v Bell, 991 F2d 1445, 1450 (8th Cir 1993) ("[T] he district court has no ability to exercise discretion because its power is firmly controlled by the Commission."). 
Clause. ${ }^{\text {15 }}$ Whether their efforts were successful depends on the scope of the Clause and its applicability to the Sentencing Commission.

\section{A. Overview of the Sentencing Commission}

The Sentencing Commission is an independent agency within the judicial branch. ${ }^{16}$ It is composed of seven voting members, at least three of whom are federal judges. ${ }^{17}$ Congress directed the Commission to develop a system of sentencing guidelines, which are applied by categories of offense and offender to produce determinative sentencing ranges. ${ }^{18}$ Congress also directed the Commission to "review and revise" the guidelines periodically. ${ }^{19}$ Any change adopted by the Commission becomes effective after 180 days, unless affirmatively rejected by Congress. ${ }^{20}$

Although sentencing courts have some discretion to depart from the guidelines, that discretion is severely constrained. Congress requires the sentencing court to "impose a sentence of the kind and within the range" established by the applicable guidelines "unless the court finds that there exists an aggravating or mitigating circumstance, of a kind, or to a degree, not adequately taken into consideration by the Sentencing Commission in formulating the guidelines that should result in a sentence different from that described." ${ }^{21}$ In deciding whether the Sentencing Commission adequately considered a particular circumstance, however, the judge may look only to the guidelines, policy statements, and official commentary of the Sentencing Commission. If she decides a departure is warranted, she must state her

1628 USC \& 991(a).

17 Id. The Attorney General, or her designee, is an ex officio non-voting member of the Commission. See id.

18 See 28 USC $\$ 994(b)(1)$. These two factors, offense category for the count(s) of conviction and criminal history category for the offender, determine the sentencing range in each case. See USSG $\$ 1 B 1.1$.

1928 USC $\S 994(0)$. All sentences are recorded and sent to the Commission under $\$ 994(w)$. See id. The Commission then reviews the data to determine where the guidelines need adjusting.

2028 USC $\$ 994(\mathrm{p})$.

2118 USC \& 3553(b).

22 See id. The Sentencing Manual is made up of guidelines, policy statements, and commentary. Guidelines are used by the sentencing court to determine the sentence imposed in a given criminal case. See 28 USC \& 994(a)(1). The Commission is also authorized to promulgate policy statements regarding the application of the guidelines or other aspects of sentencing. See 28 USC \& 994(a)(2). Policy statements are binding on federal courts. See Williams $v$ United States, 503 US 193, 201 (1992) (stating that when a policy statement "prohibits a district court from taking a specified action, the statement is an authoritative guide to the meaning of the applicable Guideline"). Finally, guidelines and policy statements are often accompanied by extensive commentary. Interpretive commentary is authoritative unless it conflicts with a guideline or federal law. See Stinson v United States, 508 US 36, 38 (1993). 
reasons on the record. ${ }^{23}$ A decision to depart is reviewable for abuse of discretion. ${ }^{24}$ In the absence of clearly erroneous findings of fact, a sentence within the range produced by proper application of the guidelines is effectively unreviewable.

Application of the sentencing guidelines to any given offender is a highly technical process. The court must go through no fewer than nine steps to determine the sentencing range. ${ }^{26}$ Part of this process involves the so-called "one book rule," which requires that the Guidelines Manual in effect on a particular date be applied in its entirety. In the policy statement adopting this rule, the guidelines reiterate the statutory requirement that the sentencing court use the Manual in effect on the date the defendant is sentenced ${ }^{28}$ However, if doing so would violate the Ex Post Facto Clause, the guidelines direct the court to use the Manual in effect when the offense of conviction was committed. ${ }^{29}$ The generic reversion from use of the guidelines in effect at the time of sentencing to those in effect at the time of the offense does not, however, tell a sentencing judge which offense controls if the defendant was convicted on multiple counts.

The Commission dealt with this issue in 1993 by adding $\S 1 \mathrm{~B} 1.11(\mathrm{~b})(3)$ to the guidelines: "If the defendant is convicted of two offenses, the first committed before, and the second after, a revised edition of the Guidelines Manual became effective, the revised edition of the Guidelines Manual is to be applied to both offenses.. ${ }^{30}$ Embodied in this provision is the Commission's conclusion that the Ex Post Facto Clause is necessarily satisfied by, at most, the use of the Manual in effect at the time the latest in a string of offenses was committed.

23 See 18 USC $\$ 3553(\mathrm{c})(2)$.

24 Koon v United States, 518 US 81, 91 (1996).

25 A defendant may appeal a sentence only if it (i) violates the law, (ii) results from an incorrect application of the Sentencing Guidelines, (iii) is greater than the statutory maximum allowed in the appropriate range under the guidelines, or (iv) is imposed for an offense for which there is no sentencing guideline and is plainly unreasonable. See 18 USC \& 3742(a).

26 See USSG $\S 1 B 1.1$. First, the judge must determine for each count which guideline applies to the offense of conviction, determine the base level of the offense, and make any necessary adjustments to the offense category based on specific characteristics of the crime. See $\S 1 \mathrm{~B} 1.1(\mathrm{a})-(\mathrm{c})$. If there are multiple counts, the court must group the counts per the grouping guidelines and make any necessary adjustments to the offense level. See $\S 1$ B1.1(d)-(e). Next the court must determine the offender's criminal history category and make any necessary adjustments thereto. See $\S 1 \mathrm{~B} 1.1(\mathrm{f})$. At this point, the court refers to the master grid to find the box corresponding to the offender's criminal history category and offense level. See $\S 1 \mathrm{~B} 1.1(\mathrm{~g})$. With the sentencing range in hand, the court must determine the sentencing options available (for example, imprisonment, fines, probation, restitution). See $\S 1 \mathrm{~B} 1.1(\mathrm{~h})$. Finally, the court must determine whether a departure from the guidelines sentence is appropriate. See $\S 1$ B1.1(i).

27 See USSG § 1B1.11(b)(2), ps.

28 See USSG \& 1B1.11(a), ps; 18 USC $\$ 3553(\mathrm{a})(4)-(5)$.

29 See USSG $\S 1 \mathrm{~B} 1.11(\mathrm{~b})(1)$, ps.

30 USSG $\S 1 \mathrm{~B} 1.11(\mathrm{~b})(3)$, ps. 
When $\S 1 \mathrm{~B} 1.11(\mathrm{~b})(3)$ is triggered, the Sentencing Commission advises that the revised Manual is to be applied even if it results in an increased penalty for the first offense, and even if the guidelines do not require the offenses be grouped for sentencing purposes. ${ }^{31}$ The Commission concluded that application of this provision does not violate the Ex Post Facto Clause because sentencing based on prior relevant conduct has been held constitutional. ${ }^{32}$ The Commission also expressed concern that the alternative approach could mean that a defendant is subject to a lower guideline range than if convicted only of the post-revision conduct. ${ }^{33}$

\section{B. Ex Post Facto Clause Jurisprudence}

While the phrase "ex post facto" is a literally meaningless term of art $^{34}$ the basic thrust of the prohibition is intuitive. Beyond constitutional common sense though, the historical scope of the Clause suggests that the Sentencing Commission's ex post facto analysis is wrong. Applying harsher guidelines retrospectively to one crime on the basis of a defendant having committed another fails to vindicate the Clause's concern with governmental restraint, even if it does provide constitutionally sufficient notice. If, however, as one circuit court judge has concluded, sentencing guidelines are not "laws" within the meaning of the Clause, ${ }^{35}$ then the fact that the ex post facto prohibition does not constrain the judiciary becomes a matter of some importance.

1. The legislature.

The Constitution provides, "No . . ex post facto Law shall be passed., ${ }^{, 36}$ As Justice Chase noted in Calder $v$ Bull, ${ }^{37}$ the prohibition "necessarily requires some explanation; for, naked and without explanation, it is unintelligible, and means nothing." ${ }^{\text {,38 }}$ From principles of English common law" and pre-Revolution usage "by legislators, law-

31 USSG § 1B1.11(b)(3), comment.

32 See id, citing United States v Ykema, 887 F2d 697, 700 (6th Cir 1989) (holding that augmented punishment for a later offense based on acts committed before a law is passed does not violate the Ex Post Facto Clause). See also Part III.B.

33 See USSG § 1B1.11(b)(3), comment. See also Part III.D.

34 Calder v Bull, 3 US (3 Dall) 385, 390 (1798) (Chase).

35 See United States $v$ Seacott, 15 F3d 1380, 1392 (7th Cir 1994) (Easterbrook concurring).

36 US Const Art I, $\$ 9$, cl 3.

373 US (3 Dall) 386 (1798).

38 Id at 390.

39 See Carmell v Texas, 529 US 513, 522-24 (2000) (noting that Justice Chase's conclusions in Calder drew heavily from Richard Wooddeson's treatise on common law, A Systematical View of the Laws of England (Thomas Payne 1792)). 
yers, and authors," ${ }^{, 40}$ Justice Chase concluded that the Clause only applies to criminal laws, and only in the following contexts:

1st. Every law that makes an action, done before the passing of the law, and which was innocent when done, criminal; and punishes such action. 2nd. Every law that aggravates a crime, or makes it greater than it was, when committed. 3rd. Every law that changes the punishment and inflicts a greater punishment, than the law annexed to the crime, when committed. 4th. Every law that alters the legal rules of evidence, and receives less, or different, testimony, than the law required at the time of the commission of the offence, in order to convict the offender."

These categories are authoritative and reiterated as a matter of course in most ex post facto decisions. ${ }^{42}$ The third category is most often the one implicated in guideline revisions, but problems analytically within the first and second may also arise.

The Supreme Court more recently also established some broad principles to guide the ex post facto inquiry. "[T]wo critical elements must be present for a criminal or penal law to be ex post facto: it must be retrospective, that is, it must apply to events occurring before its enactment, and it must disadvantage the offender affected by it." Ex Post Facto Clause does not protect an individual's right to less punishment. ${ }^{45}$ Nor does it apply to disadvantageous procedural changes. ${ }^{46}$

40 Calder, 3 US at 391.

41 Id at 390 .

42 See Rogers $v$ Tennessee, 532 US 451, 456 (2001) (referring to the cited passage as the "most well-known and oft-repeated explanation of the scope of the Clause's protection"); Carmell, 529 US at 525 (collecting cases that relied on the Calder categories).

43 See, for example, United States $v$ Suarez, 911 F2d 1016, 1022 (5th Cir 1990) (finding the application of a guideline revised to remove the scienter requirement changed the legal consequences of prior acts).

44 Weaver v Graham, 450 US 24, 29 (1981). The Court has cut back on more expansive language used in opinions relying on Weaver to read the Clause to bar anything that "substantially disadvantages" the offender. See California Dept of Corrections v Morales, 514 US 499, 506 n 3 (1995) (rejecting the language in prior cases that "suggested that enhancements to the measure of criminal punishment fall within the ex post facto prohibition because they operate to the 'disadvantage' of covered offenders"). The Ex Post Facto Clause requires a legislative change that "alters the definition of criminal conduct or increases the penalty by which a crime is punishable." Id.

45 See Weaver, 450 US at 30.

46 See Dobbert v Florida, 432 US 282, 292-98 (1977) (holding modification to a death penalty statute, which changed the respective roles of judge and jury in imposing the death sentence, did not violate the Ex Post Facto Clause); Beazell v Ohio, 269 US 167, 171 (1925) (holding the revision to a statute providing separate trials for defendants charged with embezzlement, allowing such defendants to be tried together, was not a violation of the Clause because the change was procedural). The "procedural" label, however, is more conclusory than substantive. "[W]e have long held that the question of what legislative adjustments will be held to be of sufficient moment to transgress the constitutional prohibition must be a matter of degree." Morales, 514 US at 509 (quotation marks omitted), citing Beazell, 269 US at 171. See also text accompanying 
The Clause also has been held inapplicable to retrospective application of revised parole guidelines. ${ }^{47}$ The central concerns of the Clause are the lack of fair warning and governmental restraint when the legislature increases punishment beyond what was in effect at the time the crime was committed.

2. The judiciary.

The Ex Post Facto Clause is not applicable to judicial decisionmaking. ${ }^{49}$ The Supreme Court has explicitly held that the Clause is "a limitation upon the powers of the Legislature, and does not of its own force apply to the Judicial Branch of government." textual interpretation, the Ex Post Facto Clause is targeted at the legislature. It is contained in Article I, which dictates the limitations on congressional power, and it refers explicitly to passing a "Law." Nor could the Clause feasibly apply to the judiciary, given important institutional and contextual differences between legislating and common law decisionmaking; the common law presupposes a "measure of evolution" that is incompatible with stringent application of ex post facto principles. ${ }^{\text {s1 }}$ Rather than the Ex Post Facto Clause, it is the Due Process Clause that constrains the judiciary. The due process limitations are not necessarily coextensive with those of the Ex Post Facto Clause. ${ }^{33}$ Under the Due Process Clause, the judiciary may retroactively change penal laws so long as such changes are not "unexpected and indefensible" and the defendant has "fair warning" that the changes might occur. ${ }^{54}$

notes $100-01$.

47 See Miller v United States, 482 US 423, 434-35 (1987) (discussing federal circuit court decisions rejecting ex post facto challenges to retrospective application of revised federal parole guidelines). See also cases cited in note 56.

48 See Weaver, 450 US at 30.

49 See Marks v United States, 430 US 188, 191 (1977).

50 Id (citation omitted). Even in Calder, two of the four Justices concluded that the Ex Post Facto Clause did not apply primarily because the statute in question, which set aside a specific probate court decree and granted a new hearing, was a "judicial act." See 3 US at 400 (Iredell) and $400-01$ (Cushing).

51 Rogers, 532 US at 461.

52 See Bouie v City of Columbia, 378 US 347, 354-55 (1964) ("If a state legislature is barred by the Ex Post Facto Clause from passing such a law, it must follow that a State Supreme Court is barred by the Due Process Clause from achieving precisely the same result by judicial construction.").

53 See Rogers, 532 US at $460-61$.

54 Id at 462 , quoting Bouie, 378 US at 354 . This restriction with regard to statutory law amounts to a requirement that the judiciary do a reasonable job of statutory interpretation. It is unlikely that many constructions would be struck down on appeal under the Due Process Clause as unexpected or indefensible, rather than simply struck down as a flawed interpretation of the law itself. The due process constraint is thus relevant primarily in the context of common law decisionmaking. 


\section{Whether the Ex Post Facto Clause ApPlies to RETROSPECTIVE APPLICATION OF GUIDELINE REVISIONS}

Congress arguably did not believe that the Ex Post Facto Clause would apply to amended sentencing guidelines. ${ }^{55}$ The Senate Judiciary Committee assumed that the Clause only applied to increases in the statutory maximum sentence for the same reasons that federal courts had given for upholding the Parole Commission's practice of using the guidelines in effect at the time of a prisoner's parole hearing. ${ }^{\text {s6 }}$ With regard to the sentencing guidelines, the Judiciary Committee noted,

the statutory maximum sentence applicable for an offense is unchanged by an alteration in the guidelines. Instead, the guidelines are designed to structure the exercise of discretion in making decisions, primarily to accommodate increased knowledge as to how differences among offenses or offenders should affect sentences. The guidelines do not eliminate the discretion to set a release date outside the guidelines if there is a valid reason for doing so.

As a policy matter, Congress adopted the guidelines-in-effect rule for sentencing because the use of guidelines and policy statements that were subsequently revised would create significant administrative difficulties and irrational and inconsistent sentences. ${ }^{58}$ It would also be inconsistent with the Act's philosophy of continual revision in pursuit of an ever more "sophisticated" sentencing scheme.

The Supreme Court has yet to pass on an ex post facto challenge to the application of revised federal sentencing guidelines. The closest it has come was in Miller $v$ Florida ${ }^{60}$ a challenge to retrospective ap-

55 See S Rep No 98-225, 98th Cong, 1st Sess 77-78 (1983) (Report of Senate Judiciary Committee submitted by Senator Strom Thurmond).

56 A number of courts have held that parole guidelines were not "laws" for purposes of the Ex Post Facto Clause. See Wallace $v$ Christensen, 802 F2d 1539, 1553 (9th Cir 1986) (en banc) (listing cases). See also Prater $v$ United States Parole Commission, 802 F2d 948, 951-53 (7th Cir 1986) (en banc) (explaining parole guidelines do not fall within the Clause based on text, history, and policy). Other courts reached the same result by finding either that the parole guidelines simply rationalize the exercise of statutory discretion, Warren $v$ United States Parole Commission, 659 F2d 183, 197 (DC Cir 1981), cited in Miller v United States, 482 US 423, 434 (1987), or that retrospective application does not result in a more onerous penalty. See Dufresne $v$ Baer, 744 F2d 1543, 1549 (11th Cir 1984), cited in Miller, 482 US at 434-35.

57 S Rep 98-225 at 78 (cited in note 55).

58 See id at 77.

59 "[T]he Sentencing Commission can and should continually revise its guidelines and policies to assure that they are the most sophisticated statements available and will most appropriately carry out the purposes of sentencing." Id. See also 28 USC $\$ 991$ (b)(1)(C) (stating that the Commission should update the guidelines to reflect advances in understanding of behavior); 28 USC \$ 995(a) (defining powers of the Commission necessary to perform its duties).

60482 US 423 (1987). 
plication of Florida's state guidelines. ${ }^{61}$ Under the Florida system, the state legislature implemented revisions by statute, thereby indisputably giving guideline revisions the force of law. ${ }^{62}$ One of the grounds on which the Court distinguished Florida's sentencing guidelines from the federal parole guidelines was that the former were statutorily enacted, and thus "laws" within the meaning of the Ex Post Facto Clause. $^{6}$

Following Miller, all of the federal circuit courts have held that the Ex Post Facto Clause applies to revised sentencing guidelines. ${ }^{.4}$ However, as a threshold matter, it is necessary to determine whether the federal sentencing guidelines are included in the Clause's reference to "laws." Despite almost universal reliance on Miller, eleven of the twelve circuit courts failed to acknowledge that revisions to the federal sentencing guidelines are not enacted by statute. ${ }^{66}$

61 Soon after the defendant committed the offenses of conviction, the Florida legislature made a number of changes to the state's sentencing guidelines. As a result, the defendant's presumptive sentence increased from a range of forty-two to fifty-four months imprisonment at the time the crimes were committed, to a range of sixty-six to eighty-four months at the time he was sentenced. See id at 424.

62 See id at 435 .

63 See id. For a discussion of the Court's functional reasons for distinguishing Florida's sentencing guidelines from the federal parole guidelines, see Part II.B.

64 See cases cited in note 4.

65 A number of courts have held that Apprendi v New Jersey, 530 US 466, 490 (2000), which requires that a jury find beyond a reasonable doubt any fact that results in a sentence increased beyond the statutory maximum otherwise applicable, does not apply to sentencing guidelines enhancements. See, for example, United States v Norris, 281 F3d 357, 361 (2d Cir 2002) ("Whatever 'legislative' attributes might be ascribed to the Sentencing Commission, and to whatever extent the Commission's Guidelines ranges might be considered to be 'statutory maximums,' we do not believe these ranges are statutory maximums for purposes of applying the constitutional requirements announced by the Supreme Court in Apprendi."). But see Apprendi, 530 US at 550-52 (O'Connor dissenting) (expressing concern over the effect the majority decision would have on sentencing under the guidelines).

The view that the sentencing guidelines are not maximum sentences for purposes of $A p$ prendi is in tension with the consensus view of the circuit courts that applying disadvantageous guideline revisions retrospectively violates the Ex Post Facto Clause. See cases cited in note 4. If, as the Apprendi cases conclude, the relevant maximum is the one set by statute, then it does not make sense to subject to ex post facto analysis changes to the guidelines that do not increase punishment beyond the pre-existing statutory maximum. That is, the Apprendi cases suggest the conclusion reached in this Part, that the guidelines are formally within the scope of the Clause, is wrong. On the other hand, the consensus view of the circuit courts (Judge Easterbrook notwithstanding) that retrospective application of revised guidelines implicates the Ex Post Facto Clause, suggests the Apprendi cases may be incorrect to hold that facts triggering guidelines enhancements need not be presented to the jury and found beyond a reasonable doubt. Resolving this tension, however, is beyond the scope of this Comment.

66 The exception to this formal blindness is the Seventh Circuit. After distinguishing sentencing guidelines from parole guidelines on the ground that the former are legislative, rather than interpretive rules, the majority noted that finding the Ex Post Facto Clause applicable to the federal sentencing guidelines would be "consistent" with Miller. See United States v Seacott, 15 F3d 1380, 1385-86 (7th Cir 1994). Concurring, Judge Easterbrook explicitly distinguished Miller on the ground that, there, the sentencing guidelines were "laws" for constitutional purposes. See 


\section{A. Formal Analysis}

Revisions to the sentencing guidelines are not enacted in accordance with the law-making procedures established by Article I, § 7 of the Constitution. As such, raising an ex post facto challenge to the guidelines requires a commitment to one of three positions: (1) plain text notwithstanding, the Ex Post Facto Clause is not limited to laws; (2) Congress delegated the power to make laws to the Sentencing Commission; or, (3) the ex post facto constraint is inherent in the Sentencing Reform Act itself, ${ }^{67}$ because Congress may not circumvent constitutional limits on its own authority by delegation. The first position is problematic as a matter of constitutional interpretation and the second raises a nondelegation problem the Supreme Court has already rejected. ${ }^{68}$ The third may be the most coherent solution available, if one first concludes that the promulgation of sentencing guidelines does not fit within the Judiciary's exemption from the Ex Post Facto Clause.

\section{Plain text.}

The Ex Post Facto Clause does not apply to the judiciary. ${ }^{69}$ Starting from the text of the Clause itself, there is no reason to assume that "Law" does not carry the same meaning as elsewhere in Article Icongressional enactments signed by the President or passed over his veto. ${ }^{70}$ Moreover, the Clause is phrased as an imperative: "No ... ex post facto Law shall be passed." On its face, the imperative is ad-

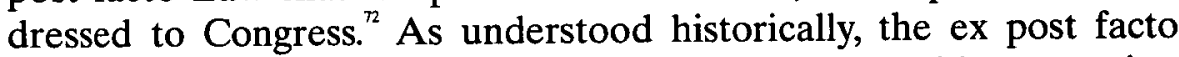
prohibition was included in the Constitution to provide protection against retrospective actions detrimental to an offender taken by Congress, not the judiciary.

id at 1392.

67 Pub L No 98-473, Ch II, 98 Stat 1987 (1984), codified as amended at 18 USC $\S \S 3551-$ 3742 (2000) and 28 USC $\$ \$ 991-98$ (2000).

68 See Mistretta v United States, 488 US 361, 371-79 (1989).

69 See Part I.B.2.

70 See US Const Art I, $\$ 7, \mathrm{cl} 2$.

71 US Const Art I, §9, cl 3 .

72 See Marks, 430 US at 191. See also Prater v United States Parole Commission, 802 F2d 948, 951-52 (7th Cir 1986) (en banc) (noting that the text and history of Clause show it was "directed to the legislative branch of government rather than to the other branches").

73 See Prater, 802 F2d at 951-52. See also Marks, 430 US at 191; Seacott, 15 F3d at 1392 (Easterbrook concurring) ("A given case could come before the one stiff sentencer on an otherwise lenient bench; the defendant sentenced to the statutory maximum, while others who committed the same crime received probation, had no complaint."). 


\section{Nondelegation.}

The argument that the Sentencing Commission makes "laws" raises a nondelegation problem, since the Constitution vests Congress alone with the legislative power granted in Article I. ${ }^{74}$ Congress may not delegate decisionmaking authority to other branches of government or to administrative agencies without guiding its execution by an intelligible principle. ${ }^{75}$ In Mistretta $v$ United States, ${ }^{76}$ the Supreme Court held that Congress had established sufficient standards for the exercise of the authority delegated to the Commission." If the Commission's power to promulgate sentencing guidelines does not present a nondelegation problem, the guidelines themselves are not laws. ${ }^{78}$

\section{Judicial exemption.}

The strongest argument that the Ex Post Facto Clause does not apply to the guidelines rests on just this principle - that the guidelines are not laws. Rather, they operate as guides to the judiciary, created by an administrative body partially composed of the judiciary. In working so hard to dispose of the nondelegation and separation of powers challenges in Mistretta, the Supreme Court seemed to adopt this view

74 US Const Art I, $\$ 1$, cl 1. But see Eric A. Posner and Adrian Vermeule, Interring the Nondelegation Doctrine, 69 U Chi L Rev 1721, 1721 (2002) ("A statutory grant of authority to the executive branch or other agents never effects a delegation of legislative power.").

75 See Whitman v American Trucking Associations, Inc, 531 US 457, 472 (2001):

In a delegation challenge, the constitutional question is whether the statute has delegated legislative power to the agency. Article I, $\S 1$, of the Constitution vests "[a]ll legislative Powers herein granted ... in a Congress of the United States." This text permits no delegation of those powers, and so we repeatedly have said that when Congress confers decisionmaking authority upon agencies Congress must lay down by legislative act an intelligible principle to which the person or body authorized to act is directed to conform.

(citations and quotation marks omitted). See also Mistretta $v$ United States, 488 US 361, 371-72 (1989) ("[W]e long have insisted ... that Congress generally cannot delegate its legislative power to another Branch.").

76488 US 361 (1989).

77 Id at 379.

78 Rather than the guidelines themselves, the formal laws are the statutory enactments authorizing and guiding the Sentencing Commission's activities: "[A]lthough Congress granted the Commission substantial discretion in formulating guidelines, in actuality it legislated a full hierarchy of punishment - from near maximum imprisonment, to substantial imprisonment, to some imprisonment, to alternatives - and stipulated the most important offense and offender characteristics to place defendants within these categories." Id at 377. To the extent that this conclusion is unsatisfactory, one is effectively agreeing with Justice Scalia, who argued:

While the products of the Sentencing Commission's labors have been given the modest name "Guidelines," they have the force and effect of laws, prescribing the sentences criminal defendants are to receive. A judge who disregards them will be reversed. I dissent from today's decision because I can find no place within our constitutional system for an agency created by Congress to exercise no governmental power other than the making of laws.

Id at 413 (Scalia dissenting) (citations omitted). The Court rejected Justice Scalia's view, however, eight to one. 
of the Sentencing Commission. The Court explained: "That Congress should vest such rulemaking in the Judicial Branch, far from being 'incongruous' or vesting within the Judiciary responsibilities that more appropriately belong to another Branch, simply acknowledges the role that the Judiciary always has played, and continues to play, in sentencing."

If the Commission is constitutional precisely because its powers are "clearly attendant to a central element of the historically acknowledged mission of the Judicial Branch," the Commission might also be understood to enjoy the judiciary's exemption from the constraints of the Ex Post Facto Clause. Prior to the guidelines regime, judges were free to set sentences anywhere within the bounds established by statutes enacted ahead of time. ${ }^{81}$ As the heirs of this judicial discretion, perhaps the Sentencing Commission should also operate without regard to the Ex Post Facto Clause, which would continue to apply solely as a constraint on the underlying statutes. ${ }^{82}$ Under this view, the sentencing guidelines should be restrained only by the less restrictive Due Process Clause. ${ }^{83}$ Congress's decision to locate the Commission in the judicial branch should not, however, end the inquiry. ${ }^{84}$

Beyond Mistretta's separation of powers analysis, there are a number of other reasons to believe that the guidelines are not "laws" within the meaning of the Ex Post Facto Clause. The guidelines do not affect the minimum and maximum penalties set by statute, nor do they typically add to or subtract from the law setting forth what is and is not prohibited. ${ }^{85}$ They are written for professionals within the criminal justice system, not for the public at large ${ }^{86}$ Moreover, judges retain some discretion to depart in either direction."

79 Id at 390-91. But see id at 427 (Scalia dissenting) (dubbing the Sentencing Commission "a sort of junior-varsity Congress").

80 Id at 391.

81 See Seacott, 15 F3d at 1392 (Easterbrook concurring).

82 See United States v Vivit, 214 F3d 908, 925 (7th Cir 2000) (Easterbrook concurring) ("What judges used to do without offending the ex post facto clause, the Sentencing Commission may do.").

83 As discussed in Part I.B.2, the judiciary is not constrained by the Ex Post Facto Clause, but rather by the Due Process Clauses of the Fifth and Fourteenth Amendments. Due process operates as a constraint on judicial interpretations of existing rules so surprising as to deprive defendants of fair notice. See Marks, 430 US at 191-92 (noting that the Ex Post Facto Clause's concern with fair notice is protected in the context of judicial decisionmaking by the Due Process Clauses).

84 See Mistretta, 488 US at 422-23 (Scalia dissenting) (arguing "Congress may divide up the government any way it wishes for nonconstitutional purposes," but that for constitutional purposes an agency belongs to the branch that controls its actions).

85 But see United States $v$ Suarez, 911 F2d 1016, 1022 (5th Cir 1990) (finding the application of a guideline revised to remove the scienter requirement changed the legal consequences of prior acts).

86 See Mistretta, 488 US at 396 ("Although the Guidelines are intended to have substantive 
On the other hand, the nature of the authority exercised by the Commission suggests that the Ex Post Facto Clause should constrain it. Unlike the Parole Commission, the Sentencing Commission exercises delegated authority to produce legislative rules that may not be disregarded by the courts. ${ }^{88}$ As such, the Commission's role in promulgating guidelines bears a striking similarity to the Supreme Court's rulemaking authority: "Just as the rules of procedure bind judges and courts in the proper management of the cases before them, so the Guidelines bind judges and courts in the exercise of their uncontested responsibility to pass sentence in criminal cases.." ${ }^{89}$ In this sense, the guidelines are more like laws than guides-judges who disregard them will be reversed. ${ }^{90}$

Moreover, the Commission does not engage in case-by-case decisionmaking, it promulgates rules of general applicability. The guidelines govern specific cases but they are developed ahead of time with the purpose and effect of constraining the sentencing discretion exercised by judges. Promulgation of the guidelines is thus decidedly unlike development of the common law, the requirements of which have been cited to justify the judicial exemption from the Ex Post Facto Clause." Ultimately, however, the dispositive factor, and one that points to the solution to this formal dilemma, is that Congress could have enacted the sentencing guidelines itself rather than empowering the Commission to handle the details. Congress ought not be able to evade constraints on its own power by delegation.

\section{Inherent constraint.}

While the Commission does not make laws, Congress does. And there is reason to think that limits on congressional power should extend to the delegation of that power. After all, "[t]he Constitution deals with substance, not shadows. Its inhibition was levelled at the thing, not the name. It intended that the rights of the citizen should be

effects on public behavior (as do the rules of procedure), they do not bind or regulate the primary conduct of the public or vest in the Judicial Branch the legislative responsibility for establishing minimum and maximum penalties for every crime."); Seacott, 15 F3d at 1392 (Easterbrook concurring) ("The tables at the time of an offense do not notify a would-be criminal that his exposure stops short of the statutory maximum.").

87 See Seacott, 15 F3d at 1392 (Easterbrook concurring).

88 See id at 1385 (distinguishing parole guidelines on this ground).

89 Mistretta, 488 US at 391.

90 See 18 USC $\S 3742$ (a) and text accompanying notes $21-25$. See also Seacott, 15 F3d at 1385 (discussing the guidelines' control over discretion of sentencing courts). The difference between the rules of procedure and the sentencing guidelines is that the former as a general matter fall within the procedural exception to the Ex Post Facto Clause. See cases cited in note 46; text accompanying notes $100-01$.

91 See Rogers, 532 US at 461. 
secure against deprivation for past conduct by legislative enactment, under any form, however disguised." post facto prohibition thus inheres in the Sentencing Commission's statutory authority to enact guidelines.

Congress may not delegate powers it does not have. ${ }^{93}$ It does not have the power to violate the Ex Post Facto Clause, so it may not authorize the Sentencing Commission to do so on its behalf. Thus, the Constitution should prohibit the Commission from requiring the courts to impose an after-the-fact increase in the punishment attached to a given offense. In particular, the courts must understand the statutory guidelines-in-effect rule as incorporating a safety-valve for ex post facto problems. Indeed, the courts forced the Commission to accept this very conclusion, which is now reflected in the guidelines. ${ }^{95}$

This understanding flies in the face of the unambiguous statutory command to apply the Manual in effect at the time of sentencing and the legislative history showing Congress did not understand the guidelines to fall within the scope of the Ex Post Facto Clause. ${ }^{96}$ Nonetheless, Congress may not avoid constitutional constraints on its own actions by delegating authority to an administrative agency. This should be true particularly with regard to the Ex Post Facto Clause, where "[i]t is the effect, not the form, of the law that determines whether it is ex post facto." Although this theory of inalienable constraints may not be entirely satisfactory as a formal matter, the functional analysis strongly suggests any ambiguity should be resolved in favor of applying the Clause to the guidelines.

\section{B. Functional Analysis}

Relying on both Miller and the Fifth Circuit's decision in United States $v$ Suarez, ${ }^{98}$ all of the circuit courts have held that application of

92 Weaver v Graham, 450 US 24, 31 n 15 (1981), quoting Cummings v Missouri, 71 US (4 Wall) 277,325 (1867).

93 See Posner and Vermeule, $69 \mathrm{U}$ Chi L Rev at 1755 (cited in note 74) (noting it is "common ground" that "Congress may not confer a power that it doesn't possess in the first place").

94 See Prater, 802 F2d at 953-54 (noting in dicta the rule against ex post facto laws should also apply to "changes in administrative regulations that represent an exercise of delegated legislative authority.... The legislature should not be allowed to do indirectly what it is forbidden to do directly.").

95 See $\$ 1 B 1.11$, comment.

96 See text accompanying notes 55-59.

97 Weaver, 450 US at 31 (rejecting the argument that change in availability of gain time credits for early release is not retrospective because, on its face, change applies only after its effective date).

98911 F2d 1016 (5th Cir 1990). The Fifth Circuit concluded that applying an adjustment to the defendant without findings of fact required under the version of the guidelines in effect at the time of her offense amounted to sentencing under the current guideline, and therefore "'would be an obvious [ ] violation' of the ex post facto clause." Id at 1021, quoting United States 
an amendment to the Sentencing Guidelines that works to an offender's detriment and takes effect after the commission of the offense violates the Ex Post Facto Clause. Well-established principles of ex post facto law indicate that this is the correct conclusion.

In 1937, the Supreme Court held that retrospective application of a statute withdrawing a judge's discretion to impose a lesser sentence violated the Ex Post Facto Clause. ${ }^{100}$ Fifty years later in Miller, the Court concluded that an amendment to Florida's guidelines that increases the "quantum of punishment" for certain categories of crimes does not fall within the procedural exception to the ex post facto prohibition. ${ }^{101}$

The Miller Court distinguished Florida's sentencing guidelines (to which the Ex Post Facto Clause did apply) from the federal parole guidelines (to which it did not) on two functional grounds. First, Florida's sentencing guidelines were inflexible, creating a "high hurdle" that had to be cleared before the sentencing judge could exercise discretion to depart. ${ }^{102}$ In addition, the revised sentencing guidelines directly and adversely affected the sentence, whereas changes in the parole guidelines left all elements of setting the punishment unaffected."

This analysis is directly applicable to the federal sentencing guidelines and suggests that retrospective application of revised guidelines should trigger the Ex Post Facto Clause. Like Florida's, the federal guidelines effectively determine the sentence imposed by placing severe restraints on the departure authority of federal judges. ${ }^{104}$ The remaining discretion is not enough to support the conclusion that judges rather than guidelines dictate defendants' sentences. ${ }^{105}$ Nor is

$v$ Woolford, 896 F2d 99, 102 n 4 (5th Cir 1990). The revision at issue was one of those rare revisions implicating the Calder category of criminalizing formerly innocent conduct. See Suarez, 911 F2d at 1022 . That is, however, essentially a more severe and more easily identifiable version of the much more common guideline revision situation, an increase in punishment for conduct already criminalized.

99 See cases cited in note 4.

100 See Lindsey $v$ Washington, 301 US 397, 401-02 (1937) (finding an ex post facto violation where a statutory change replaced a sentencing range of six months to fifteen years with a mandatory fifteen year term).

101 Miller, 482 US at 433-34. See also note 46.

102 Miller, 482 US at 435. Sentencing judges in Florida are authorized to depart from the presumptive sentencing range produced by application of the guidelines for "clear and convincing" reasons. A departure is reviewable on appeal; a sentence within the presumptive range set by the guidelines is not. Id at 426 .

103 See id at 435.

104 See 18 USC $\$ 3553(b)$; text accompanying notes 14 and 21.

105 See United States v Bell, 991 F2d 1445, 1450 (8th Cir 1993) (requiring use of more lenient sentencing guidelines in place at time crime was committed). See also Albert W. Alschuler, The Failure of Sentencing Guidelines: A Plea for Less Aggregation, 58 U Chi L Rev 901, 926-28 (1991) (arguing the sentencing guidelines regime has transferred discretion from judges to prosecutors). 
the harm to defendants from disadvantageous revisions speculativethe revisions essentially require a judge in some cases to increase the defendant's sentence over what it otherwise would have been. ${ }^{106}$

Finally, the Miller court rejected the argument that the Ex Post Facto Clause was satisfied because the offenders were on notice that sentencing guidelines may be amended, thereby subjecting them to a harsher punishment. ${ }^{107}$ In Miller, the Court explained:

Petitioner simply was warned of the obvious fact that the sentencing guidelines law-like any other law - was subject to revision. The constitutional prohibition against ex post facto laws cannot be avoided merely by adding to a law notice that it might be changed. ${ }^{108}$

If the Court applies the same scrutiny to the federal sentencing guidelines, the guidelines-in-effect rule ${ }^{109}$ is unconstitutional, as applied in certain instances. Specifically, where the Commission revises the guidelines to a defendant's disadvantage between the time of the offense and the time of sentencing, that defendant has a constitutional right to be sentenced under the old guidelines.

\section{SECTION 1B1.11(b)(3) Is UNCONSTITUTIONAL}

Section 1B1.11(b)(3) of the sentencing guidelines provides: "If the defendant is convicted of two offenses, the first committed before, and the second after, a revised edition of the Guidelines Manual became effective, the revised edition of the Guidelines Manual is to be applied to both offenses." Commission advises that the revised Manual is to be applied even if it results in an increased penalty for the first offense, and even if the guidelines do not direct the two offenses be grouped for sentencing purposes." The Commission justifies the provision by analogy to prior relevant conduct sentencing, which has been held constitutional. ${ }^{112}$ It

\footnotetext{
106 See Miller, 482 US at 432-33 (finding a harm not speculative merely because defendant could not show that the court would have imposed a lesser sentence under the old guidelines, based on a constraint on right to appeal sentence within presumptive sentencing guidelines).

107 See id at 431.

108 Id. See also Suarez, 911 F2d at 1022 (noting that finding an ex post facto violation furthers the constitutional purpose of preventing prosecution and punishment without fair warning). But see Seacott, 15 F3d at 1392 (Easterbrook concurring) ("The [Sentencing Guideline] tables at the time of an offense do not notify a would-be criminal that his exposure stops short of the statutory maximum.").

109 See 18 USC $\$ 3553(\mathrm{a})(4)(\mathrm{A})$.

110 USSG $\S 1 \mathrm{~B} 1.11(\mathrm{~b})(3)$, ps.

111 See USSG $\S 1 \mathrm{~B} 1.11(\mathrm{~b})(3)$, comment.

112 See id, citing United States v Ykema, 887 F2d 697, 700 (6th Cir 1989) (holding that augmenting punishment for a later offense based on acts committed before a law is passed does not violate the Ex Post Facto Clause).
} 
also expresses concern that an alternative approach could subject a defendant to a lesser sentence than if convicted only of the postrevision conduct. ${ }^{113}$ If $\S 1 \mathrm{~B} 1.11(\mathrm{~b})(3)$ is unconstitutional, however, a sentencing court would have to apply the older Manual, the one in effect at the time of the first crime of conviction, to all counts. ${ }^{114}$

Seven of the nine circuits to consider the issue agree with the Sentencing Commission that $\S 1 \mathrm{~B} 1.11(\mathrm{~b})(3)$ does not violate the Ex Post Facto Clause. ${ }^{115}$ The decisions rely on a number of rationales, including the following: (a) one or more provisions in the guidelines put defendants on notice that the later Manual will apply to all counts; (b) any added penalty from application of the later Manual is constitutionally equivalent to a sentencing increase for prior relevant conduct; (c) the counts of conviction constitute a single course of conduct; and (d) the alternative produces anomalously low sentences. The dispositive factor, however, given serious flaws in these arguments, is one not considered by the courts or the Commission: Increasing the punishment after a crime is committed manifests an unconstitutional lack of governmental restraint.

\section{A. Notice and Restraint}

Though not factoring into the Commission's ex post facto analysis, the courts have focused primarily on whether the defendant has been afforded notice sufficient to vindicate the Ex Post Facto Clause's concern with fair warning. The notice justification may be linked to any of a number of different provisions, including the guidelines-ineffect requirement, the provisions for revising the guidelines, $\S 1 \mathrm{~B} 1.11(\mathrm{~b})(3)$ itself, $^{116}$ the one book rule in $\S 1 \mathrm{~B} 1.11(\mathrm{~b})(2),{ }^{\mathrm{117}}$ the substantive grouping guidelines, ${ }^{118}$ or the relevant conduct guidelines. ${ }^{119}$

113 See USSG § 1B1.11(b)(3), comment.

114 An alternative approach, applying the older Manual to the older count(s) and the revised Manual to the newer, is foreclosed by the one book rule. See United States $v$ Bertoli, 40 F3d 1384, $1404 \mathrm{n} 17$ (3rd Cir 1994) (the one book rule cannot compel the application of a later manual to all counts in the face of an ex post facto problem, but it can compel the application of an earlier manual to all counts).

115 See United States v Sullivan, 255 F3d 1256, 1260 (10th Cir 2001), superseding 242 F3d 1248 (10th Cir 2001), cert denied 543 US 1166 (2002); United States v Lewis, 235 F3d 215, 219 (4th Cir 2000); United States v Vivit, 214 F3d 908, 919 (7th Cir 2000); United States v Kimler, 167 F3d 889, 895 (5th Cir 1999); United States v Bailey, 123 F3d 1381, 1406-07 (11th Cir 1997); United States v Cooper, 35 F3d 1248, 1252 (8th Cir 1994), vacd, 514 US 1094 (1995), reinstated, 63 F3d 761 (8th Cir 1995); United States v Regan, 989 F2d 44, 48 (1st Cir 1993). See also United States $v$ Tucker, 982 F Supp 1309, 1317-18 (ND Ill 1997). But see United States $v$ Ortland, 109 F3d 539, 546-47 (9th Cir 1997); Bertoli, 40 F3d at 1388, 1401 (3d Cir 1994). See also United States v Johnson, 1999 US Dist LEXIS 8819, at *28-29 (ND NY 1999), affd, 221 F3d 83 (2d Cir 2000).

116 See, for example, Lewis, 235 F3d at 218.

117 See, for example, Kimler, 167 F3d at 894-95; Bailey, 123 F3d at 1404-05.

118 See, for example, Sullivan, 255 F3d at 1262-63; Vivit, 214 F3d at 919; Kimler, 167 F3d at 894-95; Bailey, 123 F3d at 1404-05; Cooper, 35 F3d at 1250. 
Miller, however, rejected the argument that the Ex Post Facto Clause is satisfied by warning ex ante that guidelines are subject to amendment and that offenders should expect to be subjected to the version in effect at the time of sentencing.

The most important difference in the arguments that Miller did not explicitly reject is: When is notice deemed provided, prior to the commission of the first offense, or prior to commission of any postrevision offense? As discussed below, the problem with the former is that the offender is still warned only that the existing punishment might change. What the latter view lacks in timing, it makes up for in specificity. As such, this notice-by-revision approach is much more tenable, and may even vindicate the Ex Post Facto Clause's concern with fair warning. Nonetheless, it too must be rejected because it fails to account for the Ex Post Facto Clause's other concern, governmental restraint.

\section{Notice prior to the first offense.}

Some courts have concluded that $\S 1 \mathrm{~B} 1.11(\mathrm{~b})(3)$ poses no ex post facto problem because an offender is on notice before he commits the first offense that any and all offenses will be sentenced under the Guidelines Manual applicable to the latest offense. Most simply, the court may rely on the one book rule alone. ${ }^{121}$ Applicable grouping or substantive provisions that pre-date the first offense bolster the argument. ${ }^{12}$

In a relatively extreme case, United States $v$ Vivit, ${ }^{123}$ the Seventh Circuit held that there was no ex post facto problem with sentencing a defendant for sixteen counts of mail fraud under a revised guideline that included a new use-of-minors enhancement, even though only one count-and not one involving a minor-occurred after the revision. ${ }^{124}$ The court, citing Miller, noted that the Ex Post Facto Clause is implicated only when punishment is increased without prior notice. ${ }^{125}$

119 See, for example, Sullivan, 255 F3d at 1262-63; Bailey, 123 F3d at 1404-05.

120 See Miller, 482 US at 431. See also Suarez, 911 F2d at 1022 (finding an ex post facto violation in the case of a retrospective application of a disadvantageous revision to federal guidelines furthered the constitutional purpose of preventing prosecution and punishment without fair warning).

121 See, for example, Bailey, $123 \mathrm{~F} 3 \mathrm{~d}$ at 1405 ("[T]he one book rule provides notice that otherwise discrete criminal acts will be sentenced together under the Guidelines in effect at the time of the last of those acts.").

122 See, for example, Kimler, 167 F3d at 891 (noting that the pre-existing grouping rule put three pre-revision mail fraud counts together with one post-revision counterfeiting count). But see Cooper, 35 F3d at $1249-50$ (involving a situation where the grouping provision itself had been revised).

123214 F3d 908 (7th Cir 2000).

124 See id at 917.

125 See id at 919. 
Here, the majority concluded, guideline grouping rules in effect at the time of the first offense put the defendant on notice that engaging in more of the same type of conduct after a substantive revision risked having all of the counts grouped and, because of the one book rule, sentenced under a revised Manual. ${ }^{120}$

In United States $v$ Sullivan, ${ }^{12}$ a split panel of the Tenth Circuit held that applying $\S 1 \mathrm{~B} 1.11$ (b)(3) to sentence a defendant under a revised version of the guidelines for three counts of willful failure to file tax returns, two of which pre-dated the revisions, did not violate the Ex Post Facto Clause. ${ }^{128}$ The change at issue was an increase to the relevant base offense levels, which subjected the defendant to a higher sentencing range. The court found the defendant had notice prior to the commission of his first offense based on a number of provisions that did not change: the one book rule, the total tax loss provision, and the grouping and relevant conduct guidelines. ${ }^{129}$

Dissenting from the final decision, ${ }^{130}$ Judge Kelly concluded that the only notice the defendant had been given prior to committing his first offense was that he would be sentenced as per provisions that may or may not be amended. ${ }^{131}$ This, Judge Kelly argued, is precisely the sort of warning that the Supreme Court rejected as insufficient in Miller. ${ }^{132}$

The grouping provisions and one book rule notify the defendant of sentencing rules then in effect, specifically, that certain sets of offenses will be treated together for sentencing purposes. A substantive sentencing guideline, like the total tax loss provision in Sullivan, may provide this same sort of notice. However, these provisions cannot trump the Ex Post Facto Clause..$^{133}$ Moreover, insofar as they do not provide notice that the quantum of punishment may change or the manner in which it may change, they do not satisfy the Clause. ${ }^{134}$

126 See id. Concurring, Judge Easterbrook argued that the court could reach the same conclusion more directly because the Ex Post Facto Clause does not apply to sentencing guidelines. Id at 924 .

127255 F3d 1256 (10th Cir 2001), superseding 242 F3d 1248 (10th Cir 2001), cert denied, 534 US 1166 (2002).

128 Id at 1262 . The guidelines required an aggregated sentence based on the total tax loss occurring from all years in which the offender failed to pay taxes. Id.

129 See id at $1262-63$.

130 The case actually came out the other way the first time around, see 242 F3d 1248, but Judge Anderson switched sides on rehearing.

131 See 255 F3d at 1266 (Kelly dissenting).

132 See id.

133 See Bertoli, 40 F3d at 1404 (observing that neither the one book rule nor the fact that various counts of an indictment are grouped can override ex post facto concerns).

134 In Dobbert v Florida, 432 US 282 (1977), the Supreme Court held the defendant was on notice that the State would seek to impose the death penalty for certain crimes, even though the particular statute on the books at the time of the defendant's offense was subsequently found unconstitutional. See id at 298 ("[T]he existence of the [old, invalid] statute served as an 'opera- 
At most, these provisions provide a warning that punishment might change and will be imposed retrospectively. Thus a defendant is arguably given notice sufficient to convey the message that the last offense would determine his sentence, but "only a defendant with the prescience of a clairvoyant could anticipate an actual sentence based upon a yet-to-be amended guideline." ${ }^{, 135}$ It is difficult to see how this is any different from the brand of notice rejected in Miller. ${ }^{136}$

2. Notice by revision.

The stronger view is that the revisions themselves put an offender on constitutionally sufficient notice. The Eighth Circuit's is a popular formulation: "[I]t was not the amendments to the Sentencing Guidelines that disadvantaged [the defendant], it was his election to continue his criminal activity after the [ ] amendments became effective." ${ }^{137}$

In Cooper, for example, the court held that applying base-level revisions and new grouping rules to a defendant convicted of three firearms violations (two occurring prior to revision) did not violate the Ex Post Facto Clause. ${ }^{138}$ One of a number of reasons the court deployed for its conclusion was that the defendant had fair warning prior to committing the third offense that doing so would mean the increased offense levels and new grouping rules would govern any prior offenses as well. ${ }^{139}$

If notice comes from the revisions themselves, rather than preexisting sentencing rules, the Miller problem is arguably avoided. That is, the revisions give the defendant concrete notice of what the revised punishment actually will be, should he continue to engage in criminal conduct. This is an improvement over the abstract warning, relied on in Vivit and Sullivan, that punishment might change and be retrospectively applied because of the grouping and one book rules.

tive fact' to warn the petitioner of the penalty which Florida would seek to impose on him if he were convicted of first-degree murder. This was sufficient compliance with the ex post facto provision of the United States Constitution."). The Miller Court distinguished guideline revisions from the changes in Dobbert on the ground that the pre-existing guideline fails to give notice of the revised presumptive sentencing range. See 482 US at 431.

135 Sullivan, 255 F3d at 1266 (Kelly dissenting).

136 See Miller, 482 US at 431 ("The constitutional prohibition against ex post facto laws cannot be avoided merely by adding to a law notice that it might be changed."); text accompanying notes $107-08$.

137 Cooper, 35 F3d at 1250. In fact, this language is quoted even when the court's conclusion is that the defendant was on notice prior to the commission of the first offense. See, for example, Vivit, 214 F3d at 919.

138 See 35 F3d at $1250-51$.

139 See id at 1250 . See also Lewis, 235 F3d at 218 (adopting the Cooper rationale with regard to the revision adopting \$ 1B1.11(b)(3) itself); Tucker, 982 F Supp at 1316-17 (adopting the Cooper rationale with regard to the base offense level revision). 
Whether the Cooper formulation is successful depends on how rigidly one views the ex post facto restraint. The attraction of the VivitSullivan formulation (notice prior to first offense) is that the Clause seems to require notice prior to the specific offense for which punishment is inflicted; it is concerned with the punishment "annexed to the crime, when committed." What this formulation lacks, however, is specificity. It provides little more than notice that the law might change. The relatively concrete Cooper approach, on the other hand, provides a brand of notice that is arguably sufficient to vindicate the Clause's fair warning concern. Although it does apply to past conduct, the increased punishment is only triggered if the offender commits additional crimes. In a sense then, the increased punishment is annexed to the later crime, and notice is not a problem because all relevant provisions are in place when that crime is committed.

\section{Governmental restraint.}

Even if retrospective application of revised guidelines under $\S 1 \mathrm{~B} 1.11$ (b)(3) satisfies the fair warning element of the Ex Post Facto Clause, there remains a problem with a lack of governmental restraint. "Critical to relief under the Ex Post Facto Clause is not an individual's right to less punishment, but the lack of fair notice and governmental restraint when the legislature increases punishment beyond what was prescribed when the crime was consummated., ${ }^{141}$ While it might be fair to apply revisions retrospectively where they are triggered only by continued criminal conduct, doing so still runs up against the Clause's concern with governmental restraint.

The Ex Post Facto Clause is a substantive restraint on government action. It is a negative right, as are most rights in the first eight amendments, in the sense that it does not empower the individual so much as it weakens the government. The Clause restrains the legislature from increasing the punishment for a particular offense after that offense is completed. The hallmark of such unconstitutional action is typically a lack of notice. However, the focus on notice, what the individual was warned of and when, threatens to convert the Ex Post Facto Clause into a right to warning enjoyed by the individual, rather than a limit on action suffered by the government. Although this concern of the Clause is not typically analyzed separately from the fair warning concern, the Miller Court did reject Florida's attempt to re-

140 Calder, 3 US at 390 (emphasis added). See also Rogers $v$ Tennessee, 532 US 451, 470-71 (2001) (Scalia dissenting) (noting that " $[\mathrm{t}]$ here is no doubt" warning of a legislature's intention to change the law is insufficient to satisfy the Ex Post Facto Clause); Weaver v Graham, 450 US 24, 29 (1981) (disadvantageous penal laws applied to events prior to enactment violate the Ex Post Facto Clause).

141 Weaver, 450 US at 30. 
shape the Clause in this way. The more sophisticated constructive notice arguments accepted by a substantial number of federal courts are different in degree, not kind.

\section{B. Prior Relevant Conduct}

Following logically from the Cooper view that notice is provided after a first round of offenses, but before the second, courts may also justify $\S 1 \mathrm{~B} 1.11(\mathrm{~b})(3)$ by analogy to relevant conduct sentencing. ${ }^{142}$ Habitual offender laws do not violate the Ex Post Facto Clause because the later offense is deemed aggravated by the existence of related priors. ${ }^{143}$ Thus, the Commission argues, any added penalty resulting from application of $\S 1 \mathrm{~B} 1.11(\mathrm{~b})(3)$ may be deemed a result of the later crime rather than extra punishment for the earlier offense. ${ }^{144}$ The analogy fails, however, insofar as $\S 1 \mathrm{~B} 1.11(\mathrm{~b})(3)$ results in the imposition of higher sentences for the older counts, rather than relevantconduct induced sentence adjustments for the later counts.

This is the conclusion reached by the Ninth Circuit, which noted that the analogy is "not entirely logical.", 45 The fact that the harm caused by earlier offenses may be counted in sentencing a later one "does not mean that the punishment for the earlier offenses themselves can be increased." ${ }^{145}$ By its plain terms, when $\S 1 \mathrm{~B} 1.11(\mathrm{~b})(3)$ applies, it directs the court to set the sentence for multiple counts of conviction such that the sentence imposed for the earlier counts is undeniably based on changes made ex post facto. The Ninth Circuit also made the salient point that, "were the later count to fall at some time after sentencing, all that would remain would be the earlier sentences, which would be too long."147

The "prior relevant conduct" argument is compelling from a criminal justice point of view that wants to avoid rewarding more

142 See Cooper, 35 F3d at 1251; Regan, 989 F2d at 48.

143 See Gryger $v$ Burke, 334 US 728, 732 (1948) (stating that the sentence of a habitual offender is "a stiffened penalty for the latest crime, which is considered to be an aggravated offense because a repetitive one"); United States v Ykema, 887 F2d 697, 700 (6th Cir 1989) (characterizing a heavier penalty as "a statutorily authorized punishment for criminal conduct that has occurred after the passage of the law"). As the First Circuit noted, this is exactly how the guidelines system itself operates; sentences are routinely increased based on an offender's criminal history. See Regan, 989 F2d at 48 . Guidelines sentences based on relevant conduct occurring prior to the guidelines regime have been upheld against ex post facto challenges. See Tucker, 982 F Supp at 1312-13 (listing cases from four circuits).

144 See USSG \& 1B1.11(b)(3), comment. See also Regan, 989 F2d at 48 (relevant conduct provision for embezzlement brings in the whole course of conduct, even if the defendant is indicted and convicted on only a single count).

145 Ortland, 109 F3d at 547.

146 Id.

147 Id. 
crime with less time. ${ }^{148}$ Unfortunately, it is formally flawed. While it is constitutional to increase the sentence for a second crime on the basis of having committed the first, that is not what $\S 1 \mathrm{~B} 1.11(\mathrm{~b})(3)$ does. As drafted, the provision imposes a higher primary sentence for prerevision counts. Thus the relevant conduct analogy fails.

\section{Course of Conduct}

Neither can $\S 1 \mathrm{~B} 1.11$ (b)(3) be justified by analogy to continuing offenses. A number of courts upholding the provision have concluded that revision-spanning offenses may all be sentenced under revised guidelines if the offenses constitute a single course of conduct, or "unilateral conspiracy.", Applying the guidelines in effect at the end of a continuing offense, for example, conspiracy, does not implicate the Ex Post Facto Clause because a continuing offense is committed upon completion, not at inception. ${ }^{150}$ The problem with justifying $\S 1 \mathrm{~B} 1.11(\mathrm{~b})(3)$ on this ground is that each count is, by definition, discrete. Regardless of whether the collection of offenses looks like a "unilateral conspiracy" or meets the guidelines definition for a course of conduct or common scheme, ${ }^{151} \S 1 \mathrm{~B} 1.11(\mathrm{~b})(3)$ is nonetheless applied with the purpose and effect of subjecting the defendant to a harsher punishment than was in effect at the time of her offense for counts completed prior to a guidelines revision. ${ }^{152}$

148 See Tucker, 982 F Supp at 1317 ("This Court does not expect that the Seventh Circuit would agree with an analysis that results in less time for more crime.").

149 In Bailey, for example, the defendant was convicted of a series of mail fraud offenses relating to the operation of his firearms business. 123 F3d at 1389. The court concluded that the offenses composed a single guidelines group because all of the crimes were "integrally related to his ongoing purpose of deriving money from the operation of [the defendant's] firearms business." and thus applied the later Manual to all counts. Id at 1406. See also Sullivan, 255 F3d at 1260 (framing the question presented as follows: "whether [the defendant's] case is more like the simple retroactive increase in punishment for a crime, or more like a sentencing enhancement or sentence for a continuing offense spanning an amendment," and ultimately concluding that the defendant's series of willful failures to file tax returns was more like the latter).

150 See Cooper, 35 F3d at 1251 (noting that this proposition is "well established").

151 See USSG \& 1B1.3(a).

152 In addition, reasonable judges may well differ as to what constitutes a discrete offense as a matter of law. Compare Ortland, 109 F3d at 547 (mail fraud is an offense completed count by count), with Bailey, 123 F3d at 1406 (series of mail fraud counts constitutes a single course of conduct). In Vivit, the court noted as a threshold matter that, since mail fraud had been held to be a completed offense for sentencing purposes, §1B1.11(b)(3) might otherwise not apply to the set of mail fraud convictions the case presented but for the grouping provisions. See 214 F3d at 918. Thus, without the argument that the pre-existing grouping provisions put the defendant on notice, see Part III.A.1, the court would have been forced to reject § 1B1.11(b)(3). 
D. Anomalous Sentences

The Sentencing Commission also argues that the alternative to $\S 1 \mathrm{~B} 1.11(\mathrm{~b})(3)$ would produce anomalous sentences..$^{153}$ The concern is that sentencing all counts under the old Manual would result in less punishment than had the defendant been found guilty only of the post-revision count(s) and sentenced under the new Manual. This policy argument, however, surpasses its own rationale. In order to avoid the risk of giving some offenders windfalls arguably not required by the Ex Post Facto Clause, $\S 1 \mathrm{~B} 1.11(\mathrm{~b})(3)$ may ensure that some are given harsher sentences than the Clause permits. Moreover, a policy argument against "anomalous" sentences cannot trump constitutional requirements.

The Sentencing Commission provides the following example:

[I]f a defendant pleads guilty to a single count of embezzlement that occurred after the most recent edition of the Guidelines Manual became effective, the guideline range applicable in sentencing will encompass any relevant conduct (e.g., related embezzlement offenses that may have occurred prior to the effective date of the guideline amendments) for the offense of conviction. The same would be true for a defendant convicted of two counts of embezzlement, one committed before the amendments were enacted, and the second after. In this example, the ex post facto clause would not bar application of the amended guideline to the first conviction; a contrary conclusion would mean that such defendant was subject to a lower guideline range than if convicted only of the second offense. ${ }^{154}$

The Commission is concerned that sentencing both counts under the older guidelines will result in a lighter sentence than if the defendant were only convicted of the later count and sentenced under the revised guidelines. ${ }^{1.5}$ In this example, the Commission is not comparing sentencing both counts under the old Manual as against one count under the new. Rather, it is comparing sentencing both counts under the old Manual against sentencing one count as primary conduct and the other as related conduct under the new. The Commission does not want the Ex Post Facto Clause to force a conviction on two counts to

153 See USSG § 1B1.11(b)(3), comment. See also Bailey, 123 F3d at 1406-07 n 39 (noting the same anomaly); Cooper, 35 F3d at 1252 (same).

154 USSG \& 1B1.11(b)(3), comment.

155 This assumes that the Commission's example takes the one book rule into account, and thus is not comparing sentencing both counts under the new Manual with sentencing the old counts under the old and the new under the new. But see Tucker, 982 F Supp at 1317-18 (analyzing the anomaly issue in terms of applying the old manual to old counts and the new manual to new counts where the guidelines called for aggregate loss sentencing). 
result in less punishment than would result from a conviction on one count with a finding (by a preponderance of the evidence) that the conduct underlying the other occurred.'

Whether or not this is a legitimate concern, or how the guidelines would apply specifically to a pair of embezzlement or other aggregate loss offenses (for example, tax fraud), $\S 1 \mathrm{~B} 1.11(\mathrm{~b})(3)$ by its terms is not limited to groupable offenses or situations in which the older counts are relevant conduct to the newer ones. ${ }^{157}$ Moreover, even if it were so limited, the policy argument in favor of avoiding anomalous sentences cannot trump the Ex Post Facto Clause. It may be relevant to how a prosecutor exercises her charging discretion ${ }^{158}$ or how the Commission drafts the relevant conduct provisions, but it is not an appropriate consideration for determining whether $\S 1 \mathrm{~B} 1.11(\mathrm{~b})(3)$ violates the Ex Post Facto Clause.

Like the prior relevant conduct argument, the anomaly argument is premised on giving the offender his just deserts, and no less. Intellectual coherence need not be traded for flawed analogy, however. Criminal justice goals may be served simply by rewriting $\S 1 \mathrm{~B} 1.11(\mathrm{~b})(3)$ to formally sentence pre-revision counts as relevant conduct. That is, rather than requiring the court to use the revised Manual to set the primary sentence for all counts in these circumstances, the Sentencing Commission could require the court to sentence pre-revision counts as relevant conduct whenever possible. ${ }^{159}$ This would preclude $\S 1 \mathrm{~B} 1.11$ (b)(3) from outstripping its rationale - if it is justified based on anomalies associated with the relevant conduct provisions, then it should only apply where the older counts are relevant conduct to the new.

Even when the sentencing regime does not call for aggregation, the one book rule has taken the middle ground (sentencing the old counts under the old Manual and the new counts under the new) off the table. Thus, part of the problem may be that the courts and the Commission are attempting to choose between sentencing all counts,

156 See USSG $\S 1$ B1.3(a) (specifying the relevant conduct factors for use in determining the applicable guideline range); USSG $\S 6 \mathrm{A1} 1.3$, comment (advising that the preponderance of the evidence standard is sufficient for a hearing on disputed sentencing factors). It is in this regard that the reluctance to extend Apprendi to sentencing guidelines enhancements is most problematic. See note 65 .

157 See USSG $\S 1 \mathrm{~B} 1.11(\mathrm{~b})(3)$, ps.

158 If $\S 1 \mathrm{~B} 1.11(\mathrm{~b})(3)$ were held unconstitutional, it might inspire prosecutors to charge only post-revision conduct in certain cases and present the evidence of pre-revision counts for purposes of sentencing. This would avoid the problem of a jury convicting the defendant of prerevision conduct and forcing the judge to impose a sentence for all counts based on the older guidelines (assuming the one book rule were retained). On the other hand, presenting the jury with fewer formal counts might decrease the prosecutor's chance of getting a conviction at all.

159 Whatever problem there might be with the guidelines' approach to relevant conduct sentencing, it does not implicate the Ex Post Facto Clause. 
pre- and post-revision, under the old Manual and sentencing all counts under the new. The Ex Post Facto Clause does not require the former, and it prohibits the latter.

\section{CONCLUSION}

Since the Ex Post Facto Clause applies to the federal sentencing guidelines, $\S 1 \mathrm{~B} 1.11$ (b)(3) is unconstitutional because of the lack of governmental restraint inherent in retrospective application of revised guidelines. The judiciary's preoccupation with notice and the Commission's reliance on the relevant conduct analogy and concern with sentencing anomalies are manifestations of the same problem: an undue focus on what is fair to the defendant. The Ex Post Facto Clause is first and foremost a substantive constraint on government action. It is only concerned with fairness as a secondary matter. The Commission and the courts ought to move the inquiry past fairness to the defendant and recognize that the Clause requires the government to exercise some restraint. The Constitution does not permit imposing a penalty increased ex post facto for one crime simply because the defendant managed to commit another before getting caught. 